\title{
Asymmetric Cointegration between Services Exports and Economic Growth in Sri Lanka: Based on Nonlinear ARDL Model
}

\author{
EAC PRIYANKARA ${ }^{1, a}$, Zhao-Hua LI ${ }^{2, b^{*}}$ \\ ${ }^{1,2}$ School of Economics, Huazhong University of Science \& Technology, \\ Wuhan, Hubei, P.R. China \\ aeacpriyankara@yahoo.com, bzhaohuali@hust.edu.cn
}

Key words: Nonlinear autoregressive distributed lag (NARDL) model, Services exports, Asymmetric, Cointegration, Economic growth, Sri Lanka.

\begin{abstract}
This study examines the asymmetric cointegration between services exports and economic growth in Sri Lanka. A nonlinear ARDL model is employed to analyze on the annual time series data over the period from 1984-2013.The results show that(1) ignorance of asymmetries between services exports and economic growth may lead towards misleading conclusions. (2) there is statistically significant difference in the response of economic growth to positive and negative shocks to the services exports both in long- and short-run. (3) the long-run coefficient of decreasing services exports is -0.65434 and it is six time lager than the coefficient (0.10917) of increasing services exports. Hence, economic growth is more sensitive to the downturn of services exports than upturn. This empirical evidence of asymmetries could be of important in advocating services exports policies in achieving long-run economic growth in Sri Lanka.
\end{abstract}

\section{Introduction}

The main objective of this paper is to examine long-run asymmetric relationship between services exports and economic growth in Sri Lanka. Available researches on this topic have considered linear cointegration, yet, findings from such analysis are invalid under the presence of asymmetries. By mid 1980s, a group of researchers argued about asymmetries in macroeconomic variables [15] and it has become a stylized fact in the business cycle analysis. The present study motivated by these developments and accounts for if and how asymmetries presence in the case of services exports and economic growth, employing nonlinear autoregressive distributed lag (NARDL) model advanced by [6]. The initial value of services exports series is divided in to its positive and negative increments and take the positive and negative cumulative sums. The asymmetric cointegration is examined analyzing the multivariate combinations arising from such decomposition.

\section{Background}

Convincing the economic transformation process, GDP share of services accounts for $56.3 \%$ in 2015 , reaching services exports to $7 \%$ of GDP, accounting for $19.77 \%$ of total exports on average (1984-2013) in Sri Lanka. From 2000 to 2015, Sri Lanka's share of services exports in the world market increased by $114.9 \%$ showing better performance against the downturn of the share of merchandize exports by $24.6 \%$ [7]. The surplus from services exports reduces the pressure on BOP, against the continuous deficit from goods trade in Sri Lanka.

\section{Contributions}

This study enriches the existing literature in following ways. (1) this study, for the first time, relaxes the assumption of linearity in related previous studies and examines the nonlinearity of coefficient of services exports. (2) focuses on services exports-economic growth relationship, which is scant in available literature. 


\section{Literature Review Regarding the Relationship between Services Exports and Economic Growth}

This section briefs the previous empirical research on the linear or symmetric impact of services exports on economic growth and the focus is on findings. The study by [8]found services exports significantly and positively influence on economic growth in developing countries. Moreover, the author found the overall impact of services exports on economic growth was stable than that of merchandise exports during 1990s. Another work by [9] using time series data, found services export-led growth in India. The study by[10]failed to find long-run equilibrium relationship between total exports and none-exports GDP, and found empirical supports for services exports enhancing non-exports GDP when the total exports decomposed in to its components. The common limitation of all these studies is that they all assumed linear relationship-we bridge this gap through this study.

\section{Data, Empirical Methodology and Results}

Data Sources and Treatment. The data (in million US\$) gathered from UNCTAD [11], and Asian Development Bank[12] from 1984 to 2013.Exports values are deflated by GDP deflator [13]. Following[14] and [15]we defined the independent variable as GDP net of services exports. The data are in real terms and converted into log form.

Model Specification. Incorporating the positive and negative increments to services exports, growth model in equation (1) was constructed. In equation (1) GDP is the gross domestic product, $\mathrm{SX}$ is services exports and the term " $\mathrm{t}$ " refers to time. $\beta_{0}, \beta_{1}{ }^{+}$and $\beta_{1}$ ' are long-run parameters.

$$
G D P_{t}=\beta_{0}+\beta_{1}^{+} S X_{t}^{+}+\beta_{1}^{-} S X_{t}^{-}+U_{t}
$$

$\mathrm{SX}_{\mathrm{t}}^{+}$and $\mathrm{SX}_{\mathrm{t}}^{-}$are partial sum of positive and negative changes in $\mathrm{SX}_{\mathrm{t}}$ that are defined as follows.

$$
S X_{t}^{+}=\sum_{j=1}^{t} \Delta S X_{t}^{+}=\sum_{j=1}^{t} \max \left(\Delta S X_{j}, 0\right) ; \quad S X_{t}^{-}=\sum_{j=1}^{t} \Delta S X_{t}^{-}=\sum_{j=1}^{t} \min \left(\Delta S X_{j}, 0\right)
$$

NARDL Cointegration Methodology. According to the argument by[16], standard cointegration is a special case of hidden cointegration. If the components of time series are integrated, there is hidden cointegration; called as nonlinear cointegration. This is the reason that why we apply NARDL by[6] which captures the asymmetries in the both long and short-run. The NARDL approach does not require pre-testing of series and is applicable irrespective of whether the series are purely integrated at levels $[\mathrm{I}(0)]$, purely integrated at first difference [I(1)] or mixture of both. Following [6]we re-construct the model (1) as following error correction model.

$$
\begin{aligned}
\Delta G D P_{t}=\propto_{0}+ & \rho G D P_{t-1}+\theta^{+} S X_{t-1}^{+}+\theta^{-} S X_{t-1}^{-} \\
& +\sum_{j-1}^{p-1} \gamma_{j} \Delta G D P_{t-j}+\sum_{j=0}^{q-1}\left(\pi_{j}^{+} \Delta S X_{t-j}^{+}+\pi_{j}^{-} \Delta S X_{t-j}^{-}\right)+e_{t}
\end{aligned}
$$

Where $\alpha, \rho, \theta^{+}$, and $\theta^{-}$are long-run parameters while $\gamma, \pi^{+}$and $\pi^{-}$are short-run parameters. Two types of test was performed to test the null hypothesis of "no long-run relationship exits". (1) tstatistics of [17], $\mathrm{H}_{0}: \rho=0$ against the $\mathrm{H}_{1}: \rho<0$. (2) the joint null hypothesis of $\mathrm{H}_{0}: \rho=\theta^{+}=\theta^{-}=0$ using the F-test of [18] and[19]. If $\mathrm{H}_{0}$ is rejected at statistically significant level, the conclusion is that there is long-run relationship among targeted variables. The long-run coefficient of $\mathrm{SX}^{+}$and $\mathrm{SX}^{-}$are obtained as $\beta_{1}{ }^{+}=-\theta^{+} / \rho$ and $\beta_{1}{ }^{-}=-\theta^{-} / \rho$ respectively. The Wald test is applied to examine the long-run $\left(\mathrm{H}_{0}: \beta_{1}^{+}=\beta_{1}{ }^{-}\right)$and short-run $\left(\mathrm{H}_{0}: \sum_{\mathrm{j}=0}^{\mathrm{q}} \pi_{\mathrm{j}}^{+}=\sum_{\mathrm{j}=0}^{\mathrm{q}} \pi_{\mathrm{j}}{ }^{-}\right)$asymmetries[18].

Unit Root and Symmetric Cointegration Tests. We performed augmented Dickey Fuller (ADF)[20] and Phillips- Perron (PP)[21] unit root tests in order to confirm that none of the variable is $I(2)$, as ARDL bound test provides critical values for only $I(0)$ and $I(1)$ variables. Results reported 
in the Table 1 show that all the variables are $I(1)$. After we test the order of integration of the variables, usual linear cointegration test i.e. [22] and [23, 24]tests were performed. The ADF test statistic for residuals of Engle and Granger cointegration test (EG) (-1.8745) was less than even at $10 \%$ level critical values (-3.452) of[25] and accepted the null of "no cointegration". Table 2 depicts both Trace statistic and Max-Eigen value of Johansen cointegration (JJ) test accepted the null of 'no cointegration'.

Table 1. ADF and PP unit root test results for variables at first difference with constant $\&$ trend

\begin{tabular}{|c|c|c|c|c|}
\hline Unit root test/variable & $\Delta \mathrm{LGDP}$ & $\Delta \mathrm{LSX}$ & $\Delta \mathrm{LSX}^{+}$ & $\Delta \mathrm{LSX}^{-}$ \\
\hline $\mathrm{ADF}$ & $-4.099^{* *}$ & $-4.372^{*}$ & $-5.443^{*}$ & $-4.688^{*}$ \\
\hline $\mathrm{PP}$ & $-4.108^{* *}$ & $-6.938^{*}$ & $-5.734^{*}$ & $-4.823^{*}$ \\
\hline
\end{tabular}

Note: $*$, and $* *$ indicate significant at $1 \%$, and $5 \%$ respectively.

Table 2. Results of Johansen ( JJ) cointegration test

\begin{tabular}{|ll|l|l|l|ll|l|l|l|}
\hline \multicolumn{2}{|c|}{ Hypothesis } & Trace stat & Critical & Prob. & \multicolumn{2}{|l|}{ Hypothesis } & Max-Eigen & Critical & Prob. \\
$\mathrm{H}_{0}$ & $\mathrm{H}_{1}$ & value & value & & $\mathrm{H}_{0}$ & $\mathrm{H}_{1}$ & value & value & \\
\hline $\mathrm{r}=0$ & $\mathrm{r} \geq 1$ & 10.28718 & 15.49471 & 0.2593 & $\mathrm{r}=0$ & $\mathrm{r} \geq 1$ & 7.483503 & 14.26460 & 0.4336 \\
\hline $\mathrm{r} \leq 1$ & $\mathrm{r} \geq 2$ & 2.803673 & 3.841466 & 0.0940 & $\mathrm{r} \leq 1$ & $\mathrm{r} \geq 2$ & 2.803673 & 3.841466 & 0.0940 \\
\hline
\end{tabular}

Critical values are at 5\%. One lag was included in the test based on AIC, SC, HQ, FPE \& LR

Result of NARDL Regression. The results of NARDL are reported in Table 3 bellow. Following general to specific procedure, final model was considered with maximum lags 4 .The series of diagnostic tests reported in the bottom panel of the Table 3 shows that the overall performance of estimated NARDL model is satisfactory hence, continued for testing cointegration.

Table 3. NARDL estimation results

\begin{tabular}{|c|c|c|c|c|c|c|c|}
\hline $\begin{array}{l}\text { Dependent } \\
\text { Variable }\end{array}$ & Coefficient & SE & p-val & $\begin{array}{l}\text { Dependent } \\
\text { Variable }\end{array}$ & Coefficient & SE & p-val \\
\hline Constant & 2.771735 & 0.77933 & 0.0039 & $\operatorname{DLSX}^{-(-3)}$ & 0.187945 & 0.06675 & 0.0156 \\
\hline $\operatorname{LGDP}(-1)$ & -0.297737 & 0.08504 & 0.0044 & DLSX & 0.134089 & 0.05570 & 0.0331 \\
\hline $\operatorname{LSX}^{+}(-1)$ & 0.032506 & 0.00994 & 0.0067 & $\operatorname{DLSX}^{+}(-2)$ & -0.023493 & 0.01027 & 0.0411 \\
\hline $\operatorname{LSX}^{-}(-1)$ & -0.194822 & 0.06039 & 0.0073 & $\operatorname{DLSX}^{+}(-1)$ & -0.020244 & 0.01045 & 0.0768 \\
\hline $\operatorname{DLSX}^{-}(-1)$ & 0.265348 & 0.06810 & 0.0021 & $\operatorname{DLSX}^{+}(-3)$ & -0.018374 & 0.01009 & 0.0938 \\
\hline $\operatorname{DLSX}^{-}(-2)$ & 0.288176 & 0.07056 & 0.0015 & $\operatorname{DLSX}^{+}(-4)$ & -0.017500 & 0.00978 & 0.0990 \\
\hline $\operatorname{DLGDP}(-3)$ & 0.532671 & 0.18961 & 0.0158 & & & & \\
\hline \multicolumn{8}{|c|}{ Diagnostic test } \\
\hline $\mathrm{R}^{2}$ & \multicolumn{3}{|l|}{0.771807} & $\chi_{\mathrm{SC}(1}^{2}$ & \multicolumn{3}{|c|}{$0.071135[0.5056]$} \\
\hline F-stat & \multicolumn{3}{|c|}{$3.382256[0.0222]$} & $\chi_{\mathrm{HC}}^{2}$ & \multicolumn{3}{|c|}{$11.27356[0.6531]$} \\
\hline DW-stat & \multicolumn{3}{|c|}{$1.986052[0.5262]$} & $\chi_{\text {ARC }}^{2}$ & \multicolumn{3}{|c|}{$0.202068[0.3379]$} \\
\hline J-B stat & \multicolumn{3}{|c|}{1.283914 [0.7897] } & $\chi_{\mathrm{FF}}^{2}$ & \multicolumn{3}{|c|}{$1.002030[0.3379]$} \\
\hline CUSSUM & \multicolumn{3}{|c|}{ Stable (figure 1) } & CUSSUM $^{2}$ & \multicolumn{3}{|c|}{ Stable (figure 1) } \\
\hline
\end{tabular}

Note: The figures in () and [] are numbers of lags included in the test and p-values respectively.

Table 4. NARDL bound test results for nonlinear cointegration

\begin{tabular}{|l|c|c|c|c|c|}
\hline \multicolumn{2}{|c|}{ Bound test values } & \multicolumn{3}{c|}{ Bounds critical values ( at 5\% level) } \\
\hline \multirow{2}{*}{ Test statistics } & Value & \multicolumn{2}{c|}{ Pesaran et al., (2001) } & \multicolumn{2}{c|}{ Narayan (2005) } \\
\cline { 3 - 6 } & & $I(0)$ & $I(1)$ & $I(0)$ & $I(1)$ \\
\hline t-statistics & $-3.500^{* *}$ & -2.86 & $-3.22^{* *}$ & - & - \\
\hline F-Statistics & $6.640212^{* *}$ & 4.94 & $5.73^{* *}$ & 5.395 & $6.350^{* *}$ \\
\hline
\end{tabular}

Note: $\mathrm{k}=1$ is considered for both[18] and [19]bounds critical values. $\mathrm{k}$ is number or regressors. (**) indicates rejection of null hypothesis at $5 \%$ level. 
Table 5. Long-run coefficients from NARDL, FMOLS and DOLS

\begin{tabular}{|l|c|c|c|}
\hline Variable & NARDL & FMOLS & DOLS \\
\hline Constant & $9.31941^{*}$ & $9.129436^{*}$ & $9.175004^{*}$ \\
\hline LSX $^{+}$ & $0.10917^{*}$ & $0.065423^{* *}$ & $0.067639^{*}$ \\
\hline LSX $^{-}$ & $-0.65434^{*}$ & $-0.713300^{*}$ & $-0.714687^{*}$ \\
\hline F-stat & $32.06580^{*}$ & $147.9117^{*}$ & $122.9760^{*}$ \\
\hline $\begin{array}{l}\text { Goodness } \\
\text { of fit }\end{array}$ & $\begin{array}{c}\text { See the } \\
\text { table 3 }\end{array}$ & $\begin{array}{l}\text { Adj.R }{ }^{2}=0.981641, \text { S.E. }=0.052688 \\
\text { Long-run variance=0.0065 }\end{array}$ & $\begin{array}{l}\text { Adj. }{ }^{2}=0.972328, \text { S.E. }=0.066160 \\
\text { Long-run variance=0.0070 }\end{array}$ \\
\hline
\end{tabular}
and $* *$ indicate significant at 1\% and 5\% level respectively. F-stat is for testing asymmetries.

Results of NARDL Cointegration Test. The test statistic of t-test (-3.500) was greater than 5\% critical value (-3.22) of [17]. The F-statistic (6.640212) also exceeds the upper bound critical values of both [18] and [19] at 5\% level. All these tests rejected the null of "no cointegration" at 5\% level confirming the GDP, $\mathrm{SX}^{+}$and $\mathrm{SX}^{-}$show long-run relationship (Table 4).

Long-run Coefficients from NARDL, FMOLS and DOLS. Motivated by presence of cointegration, long-run coefficients for $\mathrm{SX}^{+}$and $\mathrm{SX}^{-}$were estimated based on the results in Table 3 . As reported in Table 5 above, the estimated long-run coefficients of $\mathrm{SX}^{+}$and $\mathrm{SX}^{-}$are 0.10917 $(\mathrm{p}=0.0067)$ and $-0.65434(\mathrm{p}=0.0067)$,respectively. FMOLS and DOLS also yielded almost similar results in sign and magnitude, which confirm the results of NARDL are not sensitive (Table 5).
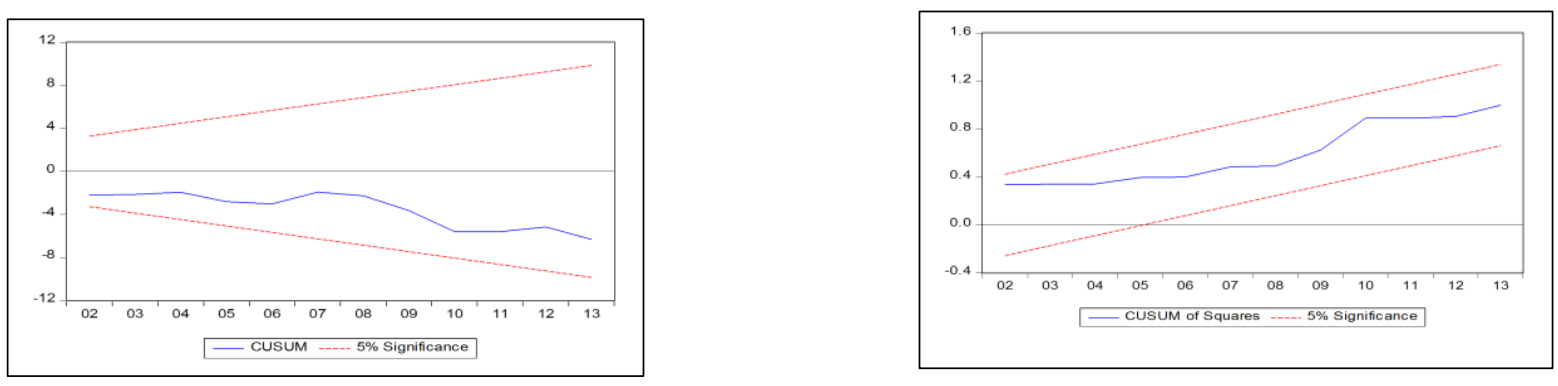

Figure1.Cumulative sums (CUSUM) and CUSUM of squired test for residuals.

Long-run Asymmetries. Wald test was performed setting the null hypothesis as $\mathrm{H}_{0}$ : $\mathrm{SX}^{+}=\mathrm{SX}^{-}$to examine the asymmetries between $\mathrm{SX}^{+}$and $\mathrm{SX}^{-}$. Results are integrated in Table 5 above. The calculated F-statistic for NARDL, FMOLS and DOLS are $\mathrm{F}=32.06580,(\mathrm{p}=0.0001), \mathrm{F}=147.9117$ $(\mathrm{p}=0.0000)$ and $122.9760(\mathrm{p}=0.0000)$ respectively. Hence, $\mathrm{H}_{0}$ is rejected at $1 \%$ level, implying the presence of asymmetries, which implies $\mathrm{SX}^{+}$influence differently from $\mathrm{SX}^{-}$on GDP. The magnitude of $\mathrm{SX}^{-}$is six time greater than magnitude of $\mathrm{SX}^{+}$. This may be due to exporting firms lay off labor and other resources to response negative shocks, however they may not employ those resources in same magnitude responding to the positive shocks.

Short-run Asymmetries.Table 3 also provides evidences for the presence of sort-run asymmetric relationships. The calculated F-statistic $(\mathrm{F}=21.36, \mathrm{p}=0.0006)$ reject the null $\left(\mathrm{H}_{0}: \sum_{\mathrm{j}=0}^{\mathrm{q}} \pi_{\mathrm{j}}^{+}\right.$ $=\sum_{\mathrm{j}=0}^{\mathrm{q}} \pi_{\mathrm{j}}^{-}$.) at $1 \%$ level.This implies the presence of short-run asymmetries. The short-run coefficients of $\mathrm{SX}^{+}$are negative and significant while that of positive and significant for $\mathrm{SX}^{-}$. The plausible explanation for the signs of coefficients is that services exported urgently may be need for sustaining the internal demand in the economy[26].

\section{Conclusions}

In this study, we account the asymmetries in the nexus between services exports and economic growth for the period from 1984 to 2013 in Sri Lanka employing the NARDL model, advanced by[6].Two standard linear cointegration test i.e.[22] and [23, 24] also performed. We find strong 
evidence for the presence of asymmetric relationship both in the long- and short-run while standard linear cointegration tests fail to find such behavior. The long-run coefficient of positive shocks to the services exports is 0.10917 while the coefficient of negative shock is -0.65434 .Our results are not sensitive and further confirmed by the FMOLS and DOLS models. Moreover, the magnitude of negative shock is six times larger than that of positive shock, which implies that the economic growth is more sensitive to downturn of services exports than upturn. This may be due to services exporting firms lay off labor and other resources to response for negative shocks, however they may not employ those resources in same magnitude responding to the positive shocks. As for the shortrun asymmetries are concerns, our findings show short-run asymmetries as well. This finding has important policy implication. Asymmetries in the relationship between services exports and economic growth should be taken into consideration in the policy-making process of services exports to achieve long-run economic growth in Sri Lanka.

\section{References}

[1] S. Lardic, V. Mignon, Oil prices and economic activity: An asymmetric cointegration approach, Energy Econ. 30(3) (2008) 847-855.

[2] J.A. Ocampo, New developments in trade theory and LDCs, J.Dev. Econ. 22 (1986) 29-170.

[3] I. Kohli, N. Singh, Exports and growth:Critical minimum effort and diminishing returns, J. Dev. Econ. 30 (1989) 391-400.

[4] T. Terasvirta, H.M. Anderson, Characterizing nonlinearities in business cycles using smooth transition autoregressive models, J. Appl. Econom. 7 (1992) S119-S136.

[5] D.K. Christopoulos, Does a non-linear mean reverting process characterize real GDP movements?, Empirical Econ. 31(3) (2006) 601-611.

[6] Y. Shin, B. Yu, M. Greenwood-Nimmo, Modelling asymmetric cointegration and dynamic multipliers in a nonlinear ARDL framework. 2014 (accessed 12.28.2017).

[7] P.-c. Athukorala, E. Ginting, H. Hill, U. Kumar, The Sri Lankan economy: Charting a new course Asian Development Bank, 2017.

[8] A. Gabriele, Exports of services, exports of goods, and economic growth in developing countries, J.Econ.Integr.21(2) (2006) 294-317.

[9] R.K. Dash, P.C. Parida, Services trade and economic growth in India: An analysis in the postreform period, Int. J. Econ.Bus. Res. 4(3) (2012) 326-345.

[10] A. Debnath, N. Roy, P. Dasgupta, N. Mazumder, On productivity differential of export composition: evidence from India, J.Chinese Econ and Foreign Trade Stud. 7(1) (2014) 38-50.

[11] Information on http://unctad.org/en/Pages/Statistics.aspx.

[12] Information on https://www.adb.org/publications/series/key-indicators-for-asia-and-the-pacific.

[13] M. Rahman, M. Mustafa, Dynamics of real exports and real economic growths in 13 selected Asian countries, J.Econ. Dev. 22(2) (1997) 81-95.

[14] S. Ghatak, C. Milner, U. Utkulu, Exports, export composition and growth :Cointegration and causality evidence for Malaysia, Appl.Econ. 29(2) (1997) 213-223.

[15] D. Herzer, F. Nowak-LehmannD, B. Siliverstovs, Export-led growth in Chile: Assessing the role of export composition in productivity growth, Deve. Econ. XLIV(3) (2006) 306-28.

[16] C.W.J. Granger, G. Yoon, Hidden cointegration, University of California San Diego. Economics Working Paper Series.2(2002)1-48. 2002. 
[17] A. Banerjee, J.J. Dolado, R. Mestre, Error-correction mechanism tests for cointegration in a single-equation framework, J. Time Ser. Anal. 19(3) (1998) 267-283.

[18] M.H. Pesaran, Y. Shin, R.J. Smith, Bounds testing approaches to the analysis of level relationships, Journal of Appl. Econom. 16 (2001) 289-326.

[19] P.K. Narayan, The saving and investment nexus for China: Evidence from cointegration tests, Appl. Econ. 37(17) (2005) 1979-1990.

[20] D.A. Dickey, W.A. Fuller, Distribution of the estimators for autoregressive time series with a unit root, J. American Statistical Association. 74(366) (1979) 427-431.

[21] P.C.B. Phillips, P. Perron, Testing for a unit root in time series regression, Biometrika. 75(2) (1988) 335-346.

[22] R.F. Engle, C.W.J. Granger, Co-integration and error correction: Representation, estimation, and testing, Econometrica. 25(2) (1987) 251-276.

[23] S. Johansen, Statistical analysis of cointegration vectors, J. Econ Dyn. Control. 12 (1988) 231254.

[24] S. Johansen, K. Juselius, Maximum likelihood estimation and inference on cointegration - with applications to the demand for money, Oxf. bull. econ. and stat. 52(2) (1990) 169-210.

[25] J.G. MacKinnon, Critical values for cointegration tests, Queen's Economics Department Working Paper No. 1227 (2010).

[26] M.N. Islam, Export expansion and economic growth: Testing for cointegration and causality, Appl.Econ. 30 (1998) 415-425. 